\title{
Adolescent Boys, Embodied Heteromasculinities and Sexual Violence
}

JAMES W. MESSERSCHMIDT ${ }^{1}$

$\approx$ In this paper the author summarizes several life history case studies of adolescent boys who were identified at school as "wimps" and who eventually engaged in various forms of sexual violence. Such boys rarely areif at all-discussed in the childhood, education and feminist literatures on sexual violence. The life stories reveal the interrelationship among inschool bullying, reflexivity, embodied structured action, and the social construction of heteromasculinities in the commission of sexual violence by subordinated boys. The author concludes by considering the implications the research has to the evolving discourses on social scientific conceptualizations of reflexive embodiment and heteromasculinities.

Keywords: bullying, reflexivity, embodiment, heteromasculinities, sexual violence

1 University of Southern Maine, Department of Sociology, Criminology, and Economics, USA; mschmidt@maine.edu. 


\section{Najstniki, utelešene heteromaskulinosti in spolno nasilje}

James W. Messerschmidt

$\propto$ V prispevku avtor povzema nekaj študij primerov življenjskih zgodb najstnikov, ki so bili deležni različnih oblik spolnega nasilja. Življenjske zgodbe razkrivajo povezanost med ustrahovanjem $\mathrm{v}$ šolah, refleksivnostjo, utelešenjem in družbenim konstruktom heteromaskulinosti pri izvajanju najstniškega spolnega nasilja. Avtor prispevek sklene $\mathrm{z}$ razpravo o implikacijah, ki jih ima raziskava na vse širšo razpravo o konceptualizacijah refleksivnega utelešenja in heteromaskulinosti v okviru družbenih ved.

Ključne besede: ustrahovanje, refleksivnost, utelešenje, heteromaskulinosti, spolno nasilje 


\section{Introduction}

Since the 1990s, I have focused much of my research on life history interviews of adolescent boys and girls involved in violence and nonviolence (Messerschmidt, 2000, 2004, 2012, 2016). The life stories of adolescent boyswhich are the subject of this paper-reveal a close relationship among in-school bullying, reflexivity, embodiment, and heteromasculinities in understanding their involvement in sexual violence. Before I begin summarizing two of the adolescent boy life history case studies, let me explain what I mean by "reflexivity," because it may be an unfamiliar term to some readers. In reflexivity we exercise our conscious mental ability to consider ourselves in relation to the particular social context and circumstances we experience (Archer, 2007). This conscious mental capacity in reflexivity involves engaging in internal conversations with ourselves about particular social experiences and then deciding how to respond appropriately. In reflexivity we internally mull over specific social events, interactions, structures and discourses, we consider how such social circumstances make us feel, we prioritize what matters most by defining our immediate concerns, and then we plan and decide how to respond (Archer, 2007). Although we internally deliberate and eventually make reflexive choices to act in particular ways, reflexivity is based on the situational and socially structured practices, discourses and interactions that we confront. Reflexivity mediates the role that social circumstances play in influencing social action and thus is indispensable in explaining particular social actions, such as sexual violence. Although individuals often engage in routine and habitual social actions (Bourdieu, 1980), I emphasize here conscious and deliberate practices that necessarily involve reflexivity.

In what follows, I first briefly explain the life history methodology used in the study. I then turn to two white working-class adolescent boys that I interviewed, both of whom ended up engaging in sexual violence. The partial synopses of these two boys' life histories serve as examples of what in-school bullying, reflexivity, embodiment, heteromasculinities and sexual violence by certain adolescent boys looks like in practice. Finally, I conclude by reflecting upon what we learn from these life stories, in particular the relationship among reflexive embodiment, heteromasculinities, and sexual violence.

\section{The Life History Method}

The paper focuses on two white working-class teenage boys from New England, USA-Sam and Zack (both pseudonyms) - who were both bullied as 
wimps. It examines how this bullying victimization is related to their specific constructions of localized heteromasculinities and eventual sexual violence. In the late 1990s, I completed life history interviews of teenage boys and girls to examine the construction and formation of gender and sexual practices through violent and nonviolent social action. Thirty youth (fifteen boys and fifteen girls) were interviewed after obtaining informed consent from each participant and their parent/guardian. A "maximum-variation" sampling procedure was used to ensure a selection of interviewees from a wide range of home life and other background situations. Although not a representative sample, the thirty life history case studies revealed the more elusive elements of teenage life that are often difficult to capture in quantifiable variables. Each life story deepens and augments our understanding of how eventual sex/gender/sexuality construction is related to personal life history.

The life history method implemented in this study involved voluntary and confidential one-on-one tape-recorded "informal conversational interviews" (Patton, 1990, pp. 280-282). These conversations were completed in two meetings of approximately three hours each. The conversations were fluid, allowing each interviewee to take the lead rather than merely respond to topical questions. The goal was to grasp each individual's unique viewpoint and thus personal vision of the world. This interview method involved attempting to foster collaboration (rather than hierarchy) in the research process by judiciously engaging each interviewee, "working interactionally to establish the discursive bases from which the respondent can articulate his or her relevant experiences" (Holstein \& Gubrium, 1995, p. 47).

This does not mean, however, that the conversations were unstructured. On the contrary, each conversation attempted to unearth the situational interactions and accomplishment of embodied practices in particular contexts and as related to personal life history. As such, the interviews sought detailed descriptions of practices (both what interviewees did in terms of practices and how they reflexively deliberated about particular social interactions and future social actions) and accounts of structured interaction in families, peer/leisure groups, schools and workplaces. The conversations touched on intimate and sensitive areas of personal life and relationships. Thus, the interviews reveal individual agentic trajectories through an assemblage of social structures in institutions and organizations.

The "data analysis" for the study had two stages. First, the tape-recorded conversations were transcribed and second, individual case studies were prepared. Here I dissect two of the life histories and define the similarities and differences between their pathways to particular forms of heteromasculinities and 
sexual violence. The goal is to capture embodied experience for each interviewee in his words. By comparing the two individual life stories of Sam and Zack I establish links between the two teenage boys who construct heteromasculinity both similarly and differently. In other words, I discover the interconnections between the two boys as well as the differences between them. Accordingly, the life history methodology helps to register patterns in lives that in other methodologies remain invisible.

\section{Sam and Zack}

In this section I present a synopsis of the two life stories, concentrating on their experiences of bullying at school and how this impacted their reflexivity and eventual embodiment of heteromasculinities and sexual violence. I begin with Sam.

\section{Sam}

Sam was a short, overweight, boyish-looking eighteen-year-old with short blonde hair. He lived with his two adoptive parents and his younger biological sister. From elementary to high school, Sam was subjected to consistent verbal bullying from the dominant "popular" boys because of his physical size and shape (he was shorter and heavier than the other boys), for his inability to respond to the bullying as the masculine culture of the school dictated-that is, to physically fight back-and for his lack of participation in sports. Sam was consistently labeled a "wimp" and was thus feminized through abusive comments made by the dominant popular boys about his inability to fight back, his nonmuscular "fat" and "wimpish" body, and his complete lack of participation in sports. Sam told me that internally: "I felt like I was a girl" (Messerschmidt, 2016, p. 69).

Sam's major concern was to be like the dominant popular boys-tough, sporty, and muscular-but he internally reasoned that his body hindered that construction; he concluded that he was bodily ill-prepared to construct this inschool dominant form of masculinity. Thus Sam's body served as an antagonist in his construction of masculinity.

At the same time that Sam was confronting this dominant-subordinate structural and discursive hegemonic masculine relationship and interaction between the bullies and himself, he simultaneously began to sexually objectify and desire girls. He learned to objectify and desire girls from interaction at school and not from his parents. Sam constantly heard the dominant popular 
boys' "sex talk" about sexual objectification of girls, as well as their alleged heterosexual exploits and experiences. He therefore began to reflexively desire to participate in heterosexuality, but he was unable to meet any girls his age. As Sam told me, he constantly had internal thoughts that centered on the bullying, which made him think, "I wasn't good enough. I didn't have the trust enough to gain access to a girl. I didn't think any girl would be interested in me" (Messerschmidt, 2016, p. 73).

Nevertheless, Sam concluded during his internal conversations that he very much desired to participate in heterosexuality because, "well, I'm a guy, so this is something that every guy does, that I want to be part of this. I want to be like the other guys. I want to know what it feels like, I want to know what goes on" (p. 72). In other words, Sam reflexively defined having sexual contact with girls as his major concern at this time in his life in order to be "like the other guys," but through his internal conversations he determined he was unable to fulfill this situationally defined dominant masculine criteria; he reflexively concluded he was unable to construct a dominant heteromasculinity at school, a construct he wholly coveted. Instead, Sam reflexively chose to turn to a masculine behavior that was available to him: expressing physical control and power over younger girls through sexuality outside the confines of school.

Sam reflexively decided that babysitting in his basement at home would be a means to satisfy his deep concern to be heteromasculine, and his parents thought babysitting was a splendid idea. He internally decided that he "wanted to have some kind of sexual experience" and he thought that through babysitting he would come into contact with "innocent" and "vulnerable" girls whom he would "be able to take advantage of easily." Sam stated that during his internal conversations he discussed with himself "how my life was, how I feared the people at school, so I figured I could get a girl I was babysitting easier. That's why I wanted to babysit” (p. 74). Consequently, Sam began babysitting a few neighborhood girls (6-8 years old) in his house after school.

In other words, Sam reflexively decided to babysit because he thought he could both physically control and gain bodily access to "vulnerable" and "innocent" girls. Once he began to babysit, he reflexively devised ways to manipulate two of the girls into fondling him and performing oral sex on him for two years. Sam internally decided upon specific strategies to gain access to the girls. As he told me: "I kept gaining ways to manipulate, ways to like bribe, like act like I was helping them, act like I was doing good things for them, like playing games with them."

In this partial synopsis of Sam's interview, then, the bullies-Sam hegemonic masculine structural relationship (Messerschmidt, 2016) and its 
co-existing feminizing discourse, as well as the culturally influential discourse at school that emphasized masculine and heterosexual objectification, desire and exploits, objectively shaped the particular social situation that Sam confronted involuntarily. During his reflexive deliberations about this situation, Sam developed and defined his major concern and what he cared about above all: to construct a heteromasculinity like the dominant popular boys at school. However, he reflexively perceived that he was unable to do this at school, and therefore subjectively developed a course of action to realize this concern; he acted to advance what he cared about above all. In so doing, Sam internally responded to the objective structures, discourses, and interactions at school by reflexively designing the course of action he pursued. Reflexivity was an emergent personal power possessed by Sam, he was an "active agent" who internally developed and determined his particular response to the social circumstances that he experienced at school. Although Sam was unable to construct heteromasculinity at school, he did not give up and become a passive victim of his circumstances. Instead, he actively used his reflexivity to devise a particular practice for himself-sexual violence-whereby he could now claim heteromasculinity as his own. And Sam saw himself as successful. In this regard, I would like to include an extended excerpt in which Sam expresses his inner thoughts on what the sexual violence accomplished for him (pp. 75-77):

I was getting away with something that nobody else that I saw was getting away with. I felt that I was number one. I didn't feel like I was small anymore, because in my own grade, my own school, with people my own age, I felt like I was a wimp, the person that wasn't worth anything. But when I did this to the girls, I felt like I was big, I was in control of everything. And that's why it was hard for me to stop, because I'd have to return to that old me of being small and not being anything. I wasn't good at sports, and tough and strong and stuff, so I wasn't fitting in with anybody that was really popular. I was like a small person, someone that nobody really paid attention to. I was the doormat at school. People walked all over me and I couldn't fight back. [And then I thought], well, I'm a guy. I'm supposed to have sex. I'm supposed to be like every other guy. And so I'm like them, but [when I did this to the girls I thought] I'm even better than them [dominant popular boys], because I can manipulate. They don't get the power and the excitement. They have a sexual relationship with a girl. She can say what she wants and she has the choice. But the girls I babysat didn't have the choice. It was like I made it look like they had a choice, but when they stated their choice, if they said no, I like bugged them and bugged them until they didn't say no. I was like better than every other guy, because there was no 
way I could get rejected. It was like, okay, they can have their relationships, I'm gonna do whatever I want. I'm better than they are.

We will now turn our attention to Zack, the second interviewee.

\section{Zack}

Zack was a short, overweight, white fifteen-year-old with short black hair who lived with his Aunt and Uncle and his two younger female cousins. Initially, he liked school and did quite well. From kindergarten to second grade, he "really excelled in school," was "doing awesome" schoolwork and had lots of friends (Messerschmidt, 2000, p. 42). In third grade, however, circumstances at school began to change. By this time, he had gained a considerable amount of weight and the other students considered him "fat," as he did himself. As Zack states, "I was really chubby and large, and I wasn't very athletic. I dressed funny. I'd wear sweat pants and the shirts with little alligators - so I wasn't popular" (p. 42). The "cool guys" at school would consistently verbally and physically bully Zack: “They'd call me 'fatty', 'chubby cheeks', 'wimp', and stuff like that. I got pushed down a lot and stuff. I got beat up a lot in the schoolyard" (p. 42).

The bullying for being short and overweight, as well as the constant physical assault, continued through grade school and middle school, especially feminizing Zack for his inability to respond to the bullying as the masculine culture of the school dictated: to physically fight back. Unlike some other boys at school, Zack did not respond physically to the bullying because he internally concluded he would be "beat up." Zack told me that he reflexively surmised that he was bodily ill-prepared to fight back because of the size and shape of his body.

In the fifth grade, however, the bullying escalated. So Zack internally decided to discuss the bullying with his uncle (whom he was very close to), and his uncle told him "you have to fight back or they'll keep it up" (pp. 42-43). So Zack reflexively decided to follow his uncle's advice because simply attempting to avoid the provoking students was not working and his major goal remained to be like the "cool guys." Consequently, during one major bullying incident in which he was persistently pushed around by a "cool guy," Zack attempted to "fight back" physically but was beaten severely: "He pile drived me into the ground." At the end of the "fight" (which took place on the playground while a large group watched), several students shouted "names at me like 'fatty', 'fatty can't fight,' 'you're a wimp,' stuff like that." I asked Zack how that made him feel and he answered, "Like I was fat, weird, and a wimp. It really bothered me 
that the cool guys at school didn't like me" (p. 43). Consequently, Zack internally decided to stop discussing the bullying with his uncle and he never again attempted to respond physically to the bullying. Like Sam, then, Zack's body served as an antagonist in his quest to construct masculinity.

Nevertheless, Zack did not give up entirely and reflexively began thinking about what he could do that would allow him to be a "cool guy." After much reflexive deliberation, he decided to try out for the junior high football team, not only because of his love of football but also to show people that he was "somebody", that he could be a "cool guy" (p. 43).

However, during the summer between fifth and sixth grades, Zack broke his wrist while attempting to "get in shape." He remained overweight and although he tried out for the team in his sixth-grade year, he was soon cut, and the verbal and physical bullying continued unabated. So Zack reflexively decided to avoid the "cool guys" as much as possible. According to Zack, the only classmates who would have anything to do with him were from a group of boys he called "the misfits." His interaction with the misfits took place only during school lunch, when they all sat together at the same lunch table. Apart from this, Zack did not "hang out" with other kids. It was through interaction with "the misfits" that he first developed a sexual interest in girls. As Zack states: "Me and the other misfits at the lunch table talked about sex and stuff. We'd see a girl sitting in the lunchroom and we'd just talk about some girls that we liked and stuff. What kind of reputation she had, what we thought about her. Nothing too gross or out of line, you know" (p. 44).

While the misfits were somewhat restrained in their discussions of sexuality at the lunch table, the dominant popular boys were extremely boisterous. As Zack told me: "They talked about it all the time. They talked about it a lot more at their table. They'd be right out loud about it, talking about 'getting laid,' and oral sex, and stuff. They always bragged about having a lot of sex and stuff" (p. 44).

Due to the frequent "sex talk" at school, Zack internally decided that he wanted to experience sex like all the other boys. Many popular boys and some of the "misfits" had allegedly engaged in intercourse, so Zack felt extremely "left out," especially since he had never been able to arrange a date. He identified himself as a "virgin," a status other boys - including numerous "misfits" - had long ago surpassed. Zack reflexively then decided to approach a few girls at school but they all, as he put it, "didn't want to go out with me because I was fat. I just didn't seem to fit in. Like I'm the only virgin in the school" (p. 45).

By age eleven, Zack had endured serious and continuous forms of bullying at school regarding his physical size and shape and for not physically 
fighting back. He reflexively defined his major concern at that time to "fit in" by adopting certain situationally accountable masculine practices: fighting back, playing football and obtaining heterosexual dates; he wanted to be a "cool guy." He failed miserably at each and had no one with whom to discuss this terribly bothersome situation. The result was that he experienced frequent internal conversations about how unhappy he was at school: "I felt really bad about myself. I thought there must be something wrong with me. I couldn't do anything right and everybody thought I was a misfit. I didn't want to be a misfit and I needed something to cheer me up" (p. 46).

Accordingly, like Sam, Zack reflexively decided to overcome his masculine dilemma by turning to controlling and dominating behaviors involving the use of sexual power. Unable to construct a heteromasculinity like the "cool guys," Zack reflexively turned to an available masculine practice: expressing control and power over his youngest female cousin through sexuality. During his sixth-grade year - a time when he experienced the distressing events just described and "discovered" heterosexuality - Zack internally decided to seek out his youngest cousin: "I wanted to experience sex, like what other boys were doing. I wanted to do what they were talking about but I was rejected by girls at school." I asked Zack to elaborate on why he turned to his youngest cousin (pp. 46-47):

She always aimed to please everyone else, so I took advantage of that. And if I let her play my [computer games], she wouldn't tell anybody. It was in the sixth grade. Me and my younger cousin, who was six at the time, we started to play this game Truth or Dare. And we just dared each other to do something. It started out pretty normal, just like standing on your head and stuff like that. But it just progressed into sexual stuff, until it was just sexual contact like oral sex and touching and stuff like that. She'd say, "No, I don't really want to," and then I'd force her into it. Like I'd say, "Oh, I'll let you play my [computer games]," because I had a [computer] and she used to always want to come and play. It started just touching over my clothing, and then it progressed to taking off each other's clothes and touching each other and stuff like that.

To satisfy his deep concern to be heteromasculine, then, Zack sexually assaulted (fondling and oral penetration) his youngest cousin over a three-year period (until he was 14 and she was 9) by using the manipulative strategy just described.

In this partial synopsis of Zack's life story, much like in Sam's story-the bullies-Zack hegemonic masculine structural relationship and its co-existing 
feminizing discourse, as well as the culturally influential discourse at school that emphasized masculine heterosexual desire and exploits, objectively shaped the particular social situation that Zack confronted involuntarily. During his reflexive deliberations about this situation, Zack (like Sam) developed and defined his major concern and what he cared about above all; to construct a heteromasculinity like the dominant "cool guys" at school so he could "fit in." However, he reflexively perceived that he was unable to do this at school and so subjectively developed a course of action to realize this concern; he acted to advance what he cared about above all. In so doing, he internally responded to the objective structures, discourses and interactions at school by reflexively designing the course of action he pursued. Like Sam, reflexivity was an emergent personal power possessed by Zack; he was an "active agent" who internally developed and determined his particular response to the social circumstances that he experienced at school. Although Zack was unable to construct heteromasculinity at school, he (again like Sam) did not give up and become a passive victim of his circumstances. Unlike Sam, he actively used his reflexivity to devise a number of particular practices - from attempting to fight back, play football and obtain heterosexual dates - but each of these strategies failed. He therefore continued to use his agency to formulate a new practice for himself - sexual violence - whereby he could claim heteromasculinity as his own. And Zack, like Sam, saw himself as successful.

In that regard, I would like to include an extended excerpt in which Zack reveals his inner thoughts as to what the sexual violence accomplished for him (p. 47):

It made me feel real good. I just felt like finally I was in control over somebody. I forgot about being fat and ugly. She was someone looking up to me, you know. If I needed sexual contact, then I had it. I wasn't a virgin anymore. I wanted control over something in my life, and this gave it to me. I finally felt like one of the guys. I was just really down because I had a rough day at school. Just a lot of teasing, being called names and being pushed around a lot. Not having any friends that meant anything. Kind of depressed about school. Not able to do things like everybody else. That made me sad. [And then I'd come home and play the game with my cousin] and that would cheer me up, make me feel better. Plus I would be sexually satisfied and feeling like I have affection. No one ever said good things about me and I never did things that the other guys did. But now I did, and it was really cool. I could now talk about sex with them if I had to. I knew what it looked like and how it felt now, that kind of thing. So I felt I fit in more. 


\section{Reflection}

The life history interviews presented here allow us to "see" genuine gendered projects as trajectories through time, as patterns of agency. Sam's and Zack's reflexivity mediated their particular social experiences at school, and it is this subjective deliberation that is essential to understanding their decision to engage in sexual violence to solve their masculine dilemma. The life history interviews with Sam and Zack recorded the particular structural, discursive and situational social conditions impacting them, they recorded the specific reflexive deliberations that mediated and negotiated those social conditions, they recorded how those social conditions made each boy feel, they recorded what each defined as their immediate concern, and they recorded how each planned and ultimately decided to engage in the crime of sexual violence. For Sam and Zack, then, it was through reflexivity that they defined their major concerns and their sense of self, that is, their perception of who they were and who they wanted to be. Reflexivity is not separate from the social but rather a dimension of it - Sam and Zack literally brought the social inside - and it is through their reflexivity that they located themselves in relation to others. Sam and Zack were not, however, free to make and remake their gendered selves as they choose; they were constrained (and enabled) by the social structures, discourses and interactions situationally available to them.

In particular, what we "see" in these life stories is both Sam and Zack attempting to practice complicity with the in-school dominant and hegemonic masculinities (Messerschmidt, 2016) and thereby - however unwittingly - reproducing gender inequality. Each case of sexual violence produced an unequal masculine/feminine relationship because it inscribed the young girls, who embody weakness and vulnerability, as feminine, and Sam and Zack, who embody strength and invulnerability, as masculine, thereby constructing "inferior" feminine survivors and "superior" masculine perpetrators. Gender difference and inequality, then, are established through Sam's and Zack's heterosexual violent practices, and we have the intersection of gender, sexuality, age and inequality through the same practice. By engaging in sexual violence, Sam and Zack simultaneously attempted to align themselves with what they reflexively perceived as the "cool guys" and their accompanying dominant and hegemonic masculinities. This process of attempted alignment resulted in both Sam and Zack constructing a dominating hegemonic masculinity whereby they were commanding and controlling the violent interaction, they were exercising aggressive and dominating power over the girls and the situation, they were calling the shots and running the show. Neither boy viewed their behavior as 
sexual violence, but rather as a legitimate and permissible way to "do" heteromasculinity: a dominating and controlling form that centered on sexual conquest. Both Sam and Zack felt entitled to sexual access and entitled to use as much manipulative coercion as necessary to succeed.

Finally, it is important to note that the bodies of Sam and Zack were reflexively scrutinized by each of them, and therefore became party to a surrogate heteromasculine practice that directed them toward a course of social action that was bodily realizable. Sam and Zack had a desperate need to abandon their feminized position and to align themselves with dominant and hegemonic masculinities (Messerschmidt, 2016). Their feminization at school was deliberated reflexively and they decided to fixate on a specific site - the home - and a specific form of body deployment - sexual violence - where such surrogate practices could be realized. At home, both Sam and Zack had access to less-powerful children, and therefore had the means through which their bodies could attain what they perceived as dominant and hegemonic masculine expressions. The contrast primarily in age and body size created a power differential that was agentic for both Sam and Zack but offensive to the young girls, who were physically, mentally and socially weaker. The available "sexual" opportunity at the home site was therefore especially attractive, became obsessive, and provided a powerful and exclusive means of doing heteromasculinity. It was in the site of the home that Sam's and Zack's bodies took on a relatively new size and shape (both were physically larger and stronger than their victims) and their bodies moved in a different way than at school (both were physically bold, competent and dominant in the home). By reflexively concentrating their interactional efforts outside the context of the school, Sam and Zack were able to transform how they interacted with and through their bodies. Both Sam and Zack were now living through their bodies in a new way and therefore they became, in their own eyes, super-heteromasculine "cool guys." 


\section{References}

Archer, M. (2007). Making Our Way Through The World: Human Reflexivity and Social Mobility. New York: Cambridge University Press.

Bourdieu, P. (1980). The Logic of Practice. New York: Polity Press

Connell, R., \& J. W. Messerschmidt (2005). Hegemonic Masculinity: Rethinking the Concept. Gender \& Society, 19(6), 829-859.

Holstein, J. A., \& J. F. Gubrium. (1995). The Active Interview. Thousand Oaks, CA: Sage.

Messerschmidt, J. W. (2000). Nine Lives: Adolescent Masculinities, the Body, and Violence. Boulder, CO: Westview Press.

Messerschmidt, J. W. (2004). Flesh \& Blood: Adolescent Gender Diversity and Violence. Lanham, MD: Rowman \& Littlefield.

Messerschmidt, J. W. (2012). Gender, Heterosexuality, and Youth Violence: The Struggle for

Recognition. Lanham, MD: Rowman \& Littlefield.

Messerschmidt, J. W. (2016). Masculinities in the Making: From the Local to the Global. Lanham, MD: Rowman \& Littlefield.

Patton, M. Q. (1990). Qualitative Evaluation and Research Methods. Newbury Park, CA: Sage.

\section{Biographical note}

JAMES W. MesserschmidT, PhD, is professor of sociology and chair of the Criminology Department at the University of Southern Maine, USA. He has written widely on masculinities and his most recent book is, Masculinities in the Making (Rowman \& Littlefield, 2016). 